\title{
Treatment of the oilfield-produced water and oil refinery wastewater by using inverse fluidization - a review
}

\author{
Al Jabri F. ${ }^{1,}{ }^{*}$, Muruganandam L. ${ }^{1}$ and Aljuboury D.A.D.A. ${ }^{2}$ \\ ${ }^{1}$ Department of Chemical Engineering, Vellore Institute of Technology University, India \\ ${ }^{2}$ School of Civil Engineering, Universiti Sains Malaysia, Malaysia \\ Received: 03/12/2018, Accepted: 18/02/2019, Available online: 20/02/2019 \\ *to whom all correspondence should be addressed: e-mail: aljabri_fathi@yahoo.com \\ https://doi.org/10.30955/gnj.002975
}

\begin{abstract}
Oilfield wastewater or produced water is a complex mixture contains oil, organic and inorganic matter and other compounds dissolved in water that ranges from fresh to brine. Discharging produced water pollute soil surface and underground water and create environment hassle. The objective of this study is to investigate and summarize the novel method of fluidization processes, used for the treatment of oilfield produced water and oil refinery wastewater. Characteristics of oilfield produced water and oil refinery wastewater from different field and various methods for treating these wastewaters are discussed. Oilfield produced water and oil refinery wastewater are strongly acidic (pH 3-4), have a high chemical oxygen demand (1200-2600 mg/L), high polyphenol content $(23 \mathrm{mg} / \mathrm{L})$ and are highly variable. Primary attention is focused on the fluidization treatment of oilfield produced water and oil refinery wastewater, mainly by inverse fluidization. Finally, areas where further research and attention are required are identified.
\end{abstract}

Keywords: Oilfield produced water, oil refinery wastewater, fluidization processes, inverse fluidization, organic matter.

\section{Introduction}

Produced water is the largest waste stream generated in oil and gas industries. It is a mixture of different organic and inorganic compounds, the properties vary widely depending on the geologic age, depth, and geochemistry of the hydrocarbon-bearing formation. $\mathrm{Du}$ to the increasing volume of waste all over the world in the current decade, the outcome and effect of discharging produced water on the environment has lately become a significant issue of environmental concern (Ahmadun et al., 2009). Produced water is conventionally treated through different physical, chemical, and biological methods. However, current technologies cannot remove small suspended oil particles and dissolved elements (Ahmadun et al., 2009).

On the other hand, because large volumes of produced water are being generated, many countries with oilfields, which are also generally water-stressed countries, are increasingly focusing on efforts to find efficient and cost-effective treatment methods to remove pollutants as a way to supplement their limited fresh water resources. Reuse and recycling of produced water include underground injection to increase oil production, use for irrigation, and various industrial uses (Veil et al., 2004). The oil refinery wastewater is difficult to treat due to large concentrations of oil. The composition of effluent in refinery wastewater depends on the crude quality. It varies with the operating conditions (Benyahia et al., 2006).

These effluents were composed of grease and petroleum compounds which consist of three main hydrocarbon groups; paraffin [very few carbon atoms], naphthene [such as cyclohexane $\left(\mathrm{C}_{6} \mathrm{H}_{12}\right)$ and dimethyl cyclopentane $\left(\mathrm{C}_{7} \mathrm{H}_{14}\right)$ ] and aromatics [The more carbon atoms a hydrocarbon molecule such as benzene $\left(\mathrm{C}_{6} \mathrm{H}_{6}\right)$, toluene $\left(\mathrm{C}_{7} \mathrm{H}_{8}\right)$ and xylene $\left(\mathrm{C}_{8} \mathrm{H}_{10}\right)$ (Aljuboury et al., 2017; Wang B., 2015). Modern methods for oil removal from wastewater include physical treatment, chemical treatment, biological treatment (Pasila, 2004), gravity separators, gas floatation devices, adsorption or absorption (Ayotamuno et al., 2006), and membrane filtration (Jian et al., 1996; Moulai-Mostefa et al., 2005).

Several types of sorbents have been studied for the removal of oil from wastewater in packed bed filters, which include hydrophobic aquatic plants (Ribeiro et al., 2003), bentonite (Viraraghavam and Moazed, 2003), vermiculite (Mysore et al., 2005), sawdust (Cambiella et al., 2006), activated carbon (Ayotamuno et al., 2006), and organoclay (Alther, 1995). Activated carbon is commercially used as a sorbent to remove oil and other organics from water (Ayotamuno et al., 2006). However, granulated activated carbon (GAC) also displays disadvantages such as slow kinetics and limited removal capacity. Thus, the search for better sorption materials which have high hydrophobicity, high uptake capacity, and high rate of efficiency is ongoing.

Fluidization is a technique through which fine solid particles behaves like a fluid through contact with liquid 
or gas, or both. Under the fluidized state, gravitational pull force on solid particles is offset by the fluid drag force so that particles remain in a semi-suspended condition. In classical fluidized bed systems, the solid particles have a higher density than the fluid - a continuous phase with an upward flow of the liquid in liquid-solid systems or with an upward co-current flow of the gas and the liquid in gas-liquid-solid systems. Fluidization can also be achieved by downward flow of liquid when solid particles are having lesser density than continuous liquid medium and it is termed as "Inverse Fluidization". The inverse fluidization has been used significantly for the treatment of industrial effluents and wastewater. Compared to conventional fluidized bed and packed bed systems, inverse fluidization has greater control over the process, higher turbulence, less solid attrition carryover of solids, higher rate of mass transfer, less clogging etc.

Inverse fluidized bed bioreactor processes are considered an interesting alternative for treating high load effluents because of their high mass transfer rate, minimum carryover of coated microorganism due to less solid attrition, efficient control of biofilm thickness and recovery of over coated particles at the bottom of the bed (Mukherjee et al., 2009; Bimal et al., 2010).

In order to meet environmental regulations as well as reuse and recycling of produced water, many researchers have focused on treating oily produced water. The oil content and salinity of produced water can be reduced through various physical, chemical, and biological methods.

The main purpose of this review is:

- To introduce oil produced water and oil refinery wastewater origin and characteristics.

- To summarize current technologies available to treat produced water.

- To focus on fluidization methods to improve effluent characteristics.

- To discuss advantages and drawbacks of the fluidization methods.

\section{Origin of oil produced water and oil refinery wastewater}

Flow from injected fluids and additives resulting from production activities and becomes produced water when saline water mixed with hydrocarbons comes to the surface (Veil et al., 2004). Transforming crude oil into useful products such as Gasoline and kerosene is achieved by the numerous refinery configurations. During these processes, the petroleum wastewater is generated in the units such as hydro-cracking, hydro-cracker flare, hydro-skimming, hydro-skimmer flare, sourwater, condensate, condensate flare, and the desalter. In addition, the main sources of total phenols at the refinery wastewater treatment plant are the neutralized spent caustic waste streams, the tank water drain and the desalter effluent (Aljuboury et al., 2017; Al Hashemi et al., 2015). In oil and gas production activities, additional water is injected into the reservoir to sustain the pressure and achieve greater recovery levels. Both formation water and injected water are produced along with hydrocarbon mixture. At the surface, processes are used to separate hydrocarbons from the produced fluid or produced water (Ekins et al., 2007).

\section{Characteristics of oil produced water and oil refinery wastewater}

The different types of organic materials typically in the oilfield-produced water and oil refinery wastewater are shown in Table 1. The most of them contented oil, grease, phenolic compounds, nitrogen, and sulphur components (Abdelwahab et al., 2009; Kavitha and Palanivelu, 2004; Lathasree et al., 2004; Pardeshi and Patil, 2008; Yang et al., 2008). The complex composition of oilfield-produced water and oil refinery wastewater is variable. Its physical and chemical properties depend on the type of hydrocarbon product being produced, the extraction method, the geological formation, and the geographic location of the field. The oilfield-produced water and oil refinery wastewater have some of the chemical characteristics of the hydrocarbon. Its characteristics and amounts can even vary throughout the lifetime of a reservoir (Veil et al., 2004).

As shown in Table 1, the major groups of components of concern in the oilfield-produced water and oil refinery wastewater are:

- Oil and Grease.

- Phenols.

- Salts (expressed as total dissolved solids (TDS)).

- Some natural chemicals that cause hardness such as calcium and magnesium.

- Chemical additives used in petroleum processes.

- BTEX (which are highly volatile).

- Acids.

The following general conclusions can be drawn from these Characteristics of oilfield-produced water and oil refinery wastewater reported by different researchers as shown in Table 1:

- The composition of effluent in the oilfieldproduced water and oil refinery wastewater depends on the sources of wastewater pollutants, the operating conditions and the crude quality. Thus, the large variance was shown in characteristics of wastewater among the investigated researches and a wide range of contaminants at varying amounts.

- The most mixtures in the oilfield-produced water and oil refinery wastewater were oil and grease which are a mixture of hydrocarbons such as BTEX (benzene, toluene, ethylbenzene, xylenes) and phenols (which are highly soluble in water). In addition, some natural chemicals that cause hardness such as calcium and magnesium.

- The average COD concentration was about $4000 \mathrm{mg} / \mathrm{L}$ and Dincer et al. (2008) reported that the COD concentration in the oilfield-produced water and oil refinery wastewater was 21000 $\mathrm{mg} / \mathrm{L}$. Thus, it is considered a high challenge to remove it by traditional treatment methods. 
Table 1 Summary of characteristics of oilfield-produced water and oil refinery wastewater in world

\begin{tabular}{|c|c|c|c|c|c|c|c|}
\hline \multirow[b]{2}{*}{ Parameter } & \multicolumn{7}{|c|}{ Reference } \\
\hline & $\begin{array}{c}\text { Saber et al. } \\
\text { (2014) }\end{array}$ & $\begin{array}{c}\text { Ahmadun et al. } \\
\text { (2009) }\end{array}$ & $\begin{array}{l}\text { Tony et al. } \\
\text { (2012) }\end{array}$ & $\begin{array}{c}\text { Gasim et al. } \\
(2012)\end{array}$ & $\begin{array}{c}\text { Jiménez et al. } \\
\text { (2017) }\end{array}$ & $\begin{array}{c}\text { Hasan et al. } \\
(2012)\end{array}$ & $\begin{array}{c}\text { Dincer et al. } \\
(2008)\end{array}$ \\
\hline Oil \& grease $(\mathrm{mg} / \mathrm{L})$ & 870 & $2-565$ & 946 & & $2-560$ & 240 & 1140 \\
\hline Magnesium & & $8-6000$ & & & $8-6000$ & & \\
\hline $\mathrm{BOD}(\mathrm{mg} / \mathrm{L})$ & 174 & & & 3378 & & 846 & 8000 \\
\hline Calcium & & $13-25800$ & & & $0-74000$ & & \\
\hline Ammonia (mg/L) & & $10-30$ & & 13.5 & $10-50$ & & 69 \\
\hline Sodium & & $132-97000$ & & & $0-150000$ & & \\
\hline Turbidity (NTU) & & & 42 & & & 83 & \\
\hline TOC (mg/L) & 119 & $0-1500$ & & & $0-1500$ & 398 & \\
\hline $\mathrm{pH}$ & 6.7 & $4.3-10$ & 7.6 & 8.48 & $4.3-10$ & 7.0 & 2.5 \\
\hline $\mathrm{COD}(\mathrm{mg} / \mathrm{L})$ & 450 & 1220 & 364 & 7896 & $1220-2600$ & 1343 & 21000 \\
\hline TSS (mg/L) & 150 & $1.2-1000$ & 105 & - & $1.2-1000$ & 74 & 2580 \\
\hline Phenols (mg/L) & & $0.009-23$ & & - & $0.009-23$ & & \\
\hline
\end{tabular}

\section{Current oilfield-produced water and oil refinery wastewater treatment techniques}

The oilfield-produced water and oil refinery wastewater treatments are classified into three types; physical, chemical and biological. Due to the complexity of characteristics of oilfield-produced water and oil refinery wastewater, the treatment need a typical method of the integrated system. Thus, the traditional treatment methods need multistage process treatment. The first stage consisted of pre-treatment, which includes mechanical and physicochemical treatments followed by the second stage which is the advanced treatment of the pretreated wastewater. Based on the literature review conducted, the methods for oilfield-produced water and oil refinery wastewater treatment included physical, chemical, biological treatment processing as shown in Table 2

Table 2 Overview of work done to treat the oilfield-produced water and oil refinery wastewater reported by various researchers

\begin{tabular}{|c|c|c|c|c|}
\hline Method & Wastewater & Removed pollutants & $\begin{array}{l}\text { Max. Removal } \\
\text { efficiency (\%) }\end{array}$ & Ref. \\
\hline $\begin{array}{l}\text { Amorphous carbon thin film } \\
\text { (ACTF) from oil palm leaves }\end{array}$ & $\begin{array}{l}\text { Synthetic produced } \\
\text { water }\end{array}$ & $\begin{array}{l}\text { oil condensate } \\
\text { concentration }\end{array}$ & $66.38 \%$ & Fathy et al. (2017) \\
\hline $\begin{array}{l}\text { The sequencing batch } \\
\text { reactor system }\end{array}$ & Petroleum wastewater & Phenols & 98 & Al Hashemi et al. (2015) \\
\hline Gas Hydrates & Produced water & Dissolved minerals & $89.2 \%$ & Fakharian et al. (2017) \\
\hline \multirow{2}{*}{$\begin{array}{l}\text { An inverse fluidized bed } \\
\text { bioreactor }\end{array}$} & \multirow{2}{*}{ Industrial wastewater } & COD removal & $87 \%$ & \multirow{2}{*}{ Arnaiz et al. (2005) } \\
\hline & & TOC removal & $92 \%$ & \\
\hline \multirow{2}{*}{ Photo-Fenton technique } & \multirow{2}{*}{$\begin{array}{c}\text { The oil refinery } \\
\text { wastewater }\end{array}$} & COD removal & $62 \%$ & \multirow{2}{*}{$\begin{array}{l}\text { Aljuboury and Palaniandy } \\
\text { (2017) }\end{array}$} \\
\hline & & IC removal & $84 \%$ & \\
\hline \multirow{2}{*}{$\begin{array}{l}\text { The reactor immobilized } \\
\text { with microorganisms }\end{array}$} & \multirow{2}{*}{$\begin{array}{l}\text { Petroleum refinery } \\
\text { wastewater }\end{array}$} & TOC & 78 & \multirow{2}{*}{ Zhao et al. (2006) } \\
\hline & & Oil & 94 & \\
\hline $\begin{array}{l}\text { The anaerobic treatment } \\
\text { process (a UASB reactor) }\end{array}$ & $\begin{array}{l}\text { Petroleum refinery } \\
\text { wastewater }\end{array}$ & COD & 82 & Gasim et al. (2013) \\
\hline The Elemir oilfield & Produced water & Oil removal & $63 \%$ & Slavko et al. (2017) \\
\hline Fenton/TiO $2 /$ UV/air & Oil-water emulsion & COD removal & $84 \%$ & Tony et al. (2009) \\
\hline
\end{tabular}

\section{The fluidization process to treat the oilfield- produced water and oil refinery wastewater}

As shown in Table 3, a previous work by CamposDíaz et al. (2017) revealed that an inverse fluidized bed bioreactor with a microbial consortium using polypropylene as support material removed $88 \%$ of COD from the wastewater generated from ethanol distillation (Vinasse). They found that inverse fluidized bed bioreactors can reduce high organic load in the wastewater generated from ethanol in short periods of time with a well acclimated microbial consortium. Arnaiz et al. (2005) showed that an inverse fluidized bed bioreactor achieved $87 \%$ of COD removal and $92 \%$ of TOC removal from industrial wastewater. Alvarado et al. (2008) reported $75 \%$ of COD removal and $95 \%$ of TOC removal from the wastewater generated from ethanol distillation (Vinasse) by using an anaerobic inverse fluidized bed reactor 
process. Sokoła, et al. (2009) showed that an inverse fluidized bed reactor containing particles made of polypropylene achieved $95 \%$ of COD removal from industrial wastewater. Alvarado et al. (2008) found that two anaerobic inverse fluidized bed reactors achieved $90 \%$ of COD removal from brewery wastewater. Wang et al. (2010) showed that an inverse fluidized bed bioreactor achieved $37 \%$ of COD removal from oil-water emulsion. They used different size ranges of surface-treated hydrophobic silica aerogels (nanogel) in an inverse fluidization mode to treat an oil-in-water emulsion. The summary of the maximum percentage COD removal (\%) by the fluidization process to treat the oilfield-produced water and oil refinery wastewater reported by various researchers are shown in Figure 1.

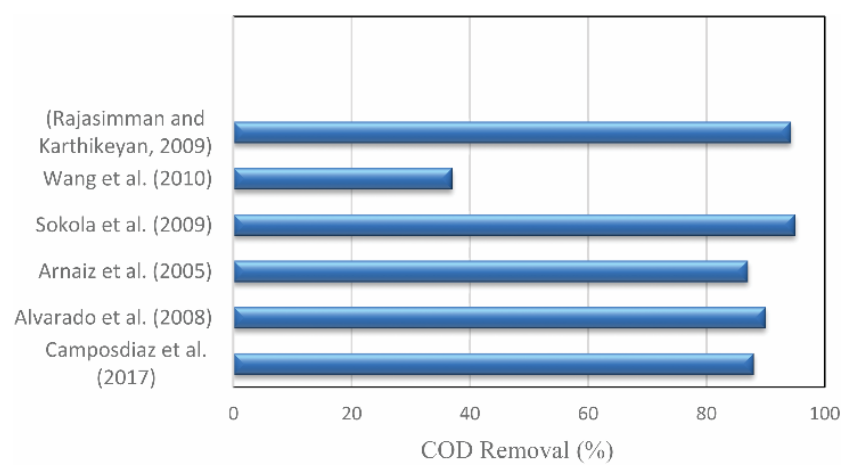

Figure 1. The maximum percentage COD removal (\%) by the fluidization process to treat the oilfield-produced water and oil refinery wastewater reported by various researchers

Table 3 Overview of work done in the fluidization process to treat the oilfield-produced water and oil refinery wastewater reported by various researchers

\begin{tabular}{|c|c|c|c|c|}
\hline Method & Wastewater & $\begin{array}{l}\text { Removed } \\
\text { pollutants }\end{array}$ & $\begin{array}{l}\text { Max. Removal } \\
\text { efficiency (\%) }\end{array}$ & Ref. \\
\hline Coupled Inverse Fluidized Bed & The wastewater & & & \\
\hline $\begin{array}{c}\text { Bioreactor with Advanced } \\
\text { Oxidation Processes }\end{array}$ & $\begin{array}{l}\text { generated from ethanol } \\
\text { distillation (Vinasse) }\end{array}$ & COD & $88 \%$ & Campos Díaz et al. (2017) \\
\hline $\begin{array}{l}\text { Two anaerobic inverse } \\
\text { fluidized bed reactors }\end{array}$ & Brewery wastewater & COD & $90 \%$ & Alvarado et al. (2008) \\
\hline \multirow{2}{*}{$\begin{array}{c}\text { An inverse fluidized bed } \\
\text { bioreactor }\end{array}$} & \multirow{2}{*}{ Industrial wastewater } & COD & $87 \%$ & \multirow{2}{*}{ Arnaiz et al. (2005) } \\
\hline & & TOC & $92 \%$ & \\
\hline \multirow{2}{*}{$\begin{array}{l}\text { An anaerobic inverse fluidized } \\
\text { bed reactor process }\end{array}$} & \multirow{2}{*}{$\begin{array}{c}\text { The wastewater } \\
\text { generated from ethanol } \\
\text { distillation (vinasse) }\end{array}$} & COD & $75 \%$ & \multirow[b]{2}{*}{ Alvarado et al. (2008) } \\
\hline & & TOC & $95 \%$ & \\
\hline $\begin{array}{l}\text { The inverse fluidized bed } \\
\text { reactor }\end{array}$ & Industrial Wastewater & COD & $95 \%$ & Sokoła, et al. (2009) \\
\hline Fenton/ $\mathrm{TiO}_{2} / \mathrm{UV} /$ air & Oil-water emulsion & COD & $84 \%$ & Tony et al. (2009) \\
\hline $\begin{array}{l}\text { The inverse fluidized bed } \\
\text { reactor }\end{array}$ & Oil-water emulsion & COD & $37 \%$ & Wang et al. (2010) \\
\hline $\begin{array}{l}\text { Inverse fluidized bed } \\
\text { bioreactor }\end{array}$ & Industrial Wastewater & COD & $94.3 \%$ & $\begin{array}{l}\text { Rajasimman and Karthikeyan } \\
\text { (2009) }\end{array}$ \\
\hline
\end{tabular}

\section{Parameters affecting the fluidization process}

Wang et al. (2018) indicate that the flow behavior of particles in an inverse liquid-solids fluidized bed with a jet is divided into three stages: particles flow downward; particles flow upwards and a dynamic balance is reached in the bed. Quality of fluidization can be improved through increasing jet speed, liquid viscosity, restitution coefficient of particles and particle density. Huang and Zhu (2017) showed that a solid baffle is essential to control the orderly liquid flow to obtain the stable inverse fluidized bed in the gas-driven inverse liquid-solid fluidized bed.

\section{Effect of fluidization velocities and pressure drop}

Minimum fluidization velocity is one of the most important parameters when characterizing the hydrodynamics of a fluidized bed. It is an important hydrodynamic parameter involved in the design of this type of system. It is defined as the lowest superficial velocity at which the downward weight of the particles the drag force due to downward flow of the liquid just counters the upward buoyancy force of the solid particles (Bimal et al., 2010). Huang and Zhu (2017) showed that the average particle velocity in the gas-driven inverse liquid-solid fluidized bed was proportional to superficial gas velocity and higher for denser particles. Upender and Kishore (2017) found that minimum fluidization velocity in liquid-solid inverse fluidized bed reactor decreased with increase in particle density and increase in particle diameter and the minimum fluidization velocity independent of the initial bed height. Alvarado et al. (2008) found that a velocity of $6 \mathrm{~m} / \mathrm{h}$ can be established for an adequate bed expansion with a minimum energy requirement for triturated polyethylene. Sokoła, et al. (2009) showed that values of COD were decreasing with an increase in gas velocity $(u g)$ up to $0.020 \mathrm{~m} / \mathrm{s}$. For velocities $(u g)$ larger than $0.020 \mathrm{~m} / \mathrm{s}$, values of COD 
were increasing with an increase in ug. This can be explained by the fact that with an increase in ug up to $0.020 \mathrm{~m} / \mathrm{s}$, an interfacial (air-liquid) area increased (Lee and Buckley, 1981). Wang et al. (2010) showed that the minimum fluidization velocity is dependent on the granule size and is independent of the amount of the granules fluidized. The larger the granule size, the higher the minimum fluidization velocity. Tisa et al. (2014) indicate that the minimum flow rate for liquid in fluidized bed reactor was $0.1617 \mathrm{~L} / \mathrm{min}$ obtained from the calculated minimum fluidization velocity and the settling velocity of the particle was $0.0365 \mathrm{~m} / \mathrm{s}$. Ali et al. (2013) showed that minimum fluidization velocity for tow tested materials was insensitive to bed height and increased with increasing the material density. The minimum fluidization velocity was correlated with dimensionless groups and independent parameters with correlation coefficient is 0.9389. Choi and Shin (1999) reported that the particle loads did not highly affect the critical rotating velocity for homogeneous fluidization while the geometry of reactor spacing and the type of impeller were more important for easy fluidization. Therefore, the inverse fluidized bed reactor using aeration is more promising for the application of wastewater treatment than that using centrifugal force.

Upender and Kishore (2017) found that the minimum fluidization $\left(U_{m f}\right)$ depends upon the pressure drop $(\Delta p)$ and the pressure drop increased with increase liquid flow rate up to minimum fluidization velocity. Wang et al. (2010) found that the pressure drop rises linearly below minimum fluidization in the packed bed region and then plateaus above minimum fluidization.

\section{Effect of bed expansion and bed height}

The distribution of particles in the bed is sensitive to particle density, and the increment of particles density improves the fluidization state through making particle distribution more uniform (Wang et al., 2018). Huang and Zhu (2017) showed that the rate of bed expansion in the gas-driven inverse liquid-solid fluidized bed was found to be faster for heavier particles and for smaller solids loading, meaning that achieving fluidization is easier under these conditions. Alvarado et al. (2008) found that an amount of support equal to $25 \%$ of the active volume for bed expansion, appeared to be adequate to obtain the best contact between microorganisms and liquid with a low energy cost. Huang and Zhu (2017) reported that bed expansion ratio in the gas-driven inverse liquid-solid fluidized bed was higher for particles with a higher density and a smaller solids loading.

Huang and Zhu (2017) reported that the fluidized bed height and total bed height increase with the increasing gas flow rate, but the packed bed height decreases. Wang et al. (2010) found that the main factors which affect the oil removal capacity of the Nanogel granules in the inverse fluidized bed and inverse packed-fluidized bed are the bed height, the size of the granules, and the fluid velocity. They reported that the fluidized bed height remains relatively constant at the beginning of the experiment until some of the Nanogels have adsorbed/absorbed an appreciable amount of oil. These particles become heavier and can no longer be suspended by the buoyancy force of the fluid, and the bed begins to expand downward towards the bottom of the column until the expanded bed height is equal to the physical length of the column at which point the experiment is stopped. Ali et al. (2013) showed that bed height variation depends on solid densities. This is due to the fact that at a low flow rate the force due to the downward flow of liquids is less than the net buoyancy force of the particles acting in the opposite direction. Hence the particles remain as a packed bed attached to the bottom distributor plate. With further increase in flow rate, a condition (net upward force just equals to net downward force) is reached where the lowest layer of the particles just starts to get detached from the bed (Ali et al., 2013).

\section{Effect of particles density}

Alvarado et al. (2008) found that low-density particles require low fluidization energy, but extendosphere particles present a better fluidization. Generally, under the tested conditions extendosphere support presents a better behavior for fluidization. Wang et al. (2010) showed that the Nanogel particles can absorb as much as 2.8 times their weight of oil by the inverse fluidization process.

\section{Conclusions}

- The oilfield-produced water and oil refinery wastewater were a danger pollution source for watercourses. They have harmful mixtures, which badly affect the environment when they are discharged into the watercourses. Thus, they were treated by physical, chemical and biological treatment processes.

- The most limits of using of the Fluidization process in the oilfield-produced water and oil refinery wastewater treatment plants were lack of knowledge and rare of the literature about this method.

- The Fluidization process were an attractive and suitable to treat the oilfield-produced water and oil refinery wastewater and has ability to remove potentially the organic and inorganic matter and cost-effective technique.

- Using of the Fluidization method in the case of commercial applications would be cheaper and was also suitable to treat the oilfield-produced water and oil refinery wastewater.

- Majority of the studies reported the major factors which affect the oil removal efficiency and capacity are the size of the particle, bed height, and fluid superficial velocity.

- Majority of the studies reported that minimum fluidization velocity in liquid-solid inverse fluidized bed reactor decreased with increase in particle density. In addition, the pressure drop increased with increase liquid flow rate up to minimum fluidization velocity. 
- The fluidized bed height and total bed height increase with the increasing gas flow rate, but the packed bed height decreases in the most of studies.

\section{References}

Abdelwahab O., Amin N.K. and El-Ashtoukhy E.-S.Z. (2009), Electrochemical removal of phenol from oil refinery wastewater. Journal of Hazardous Materials, 163, 711-716.

Ahmadun F., Pendashteha A., Chuah Abdullaha L., Biaka D.R.A., Madaenic S.S. and Abidin Z.Z. (2009), Review of technologies for oil and gas produced water treatment. Journal of Hazardous Materials, 170, 530-551.

Al Hashemi W., Maraqa M.A., Rao M.V. and Hossain M.M. (2015), Characterization and removal of phenolic compounds from condensate-oil refinery wastewater. Desalination and Water Treatment, 54, 660-671.

Ali K.A., Jawad A.H. and Ibrahim S.I. (2013), Experimental Investigation of Minimum Fluidization Velocity in Three Phase Inverse Fluidized Bed System. Engineering and Technology Journal, 31(A6), 1194-1203.

Aljuboury D.A.D. and Palaniandy P. (2017), Kinetic study of inorganic carbon (IC) removal and COD removal from refinery wastewater by solar Photo-Fenton. Global NEST Journal, 19(4), 641-649.

Aljuboury D.D.A., Palaniandy P., Abdul Aziz H.B. and Feroz S. (2017), Performance of the photocatalyst and Fenton processes to treat the petroleum wastewater - A review. Global NEST Journal, 19(3), 396-411.

Alther G.R. (1995), Organically modified clay removes oil from water, Waste Management, 15, 623-628.

Alvarado-Lassman A., Rustrian E., Garcia-Alvarado M.A., Rodriguez-Jimenez G.C. and Houbron E. (2008), Brewery wastewater treatment using anaerobic inverse fluidized bed reactors. Bioresource Technology, 99, 3009-3015.

Arnaiz C., Elmaleh S., Lebrato J., et al. (2005), Startup of an anaerobic inverse turbulent bed reactor fed with wine distillery wastewater using pre-colonised bioparticles. Water Science \& Technology, 51, 153-158.

Ayotamuno M.J., Kogbara R.B., Ogaji S.O.T. and Probert S.D. (2006), Petroleum contaminated ground-water: remediation using activated carbon. Applied Energy, 83, 1258-1264.

Benyahia F. (2006), Refinery wastewater treatment: a true technological challenge, 7th Annual U.A.E. University Res. Confer., pp. 186-194.

Bimal D., Uma P.G. and Sudip P.G. (2010), Inverse fluidization using non-newtonian liquids. Chemical Engineering and Processing: Process Intensification 49, 1169-1175.

Cambiella A. Ortea E., Rios G., Benito J.M., Pazos C. and Coca J. (2006), Treatment of oil-in-water emulsions: performance of a sawdust bed filter, Journal of Hazardous Materials, B131, 195-199.

Campos-Díaz K.E., Cruz J.L.Á., Rodríguez M.L.L. and Bandala E.R. (2017), Coupled Inverse Fluidized Bed Bioreactor with Advanced Oxidation Processes for Treatment of Vinasse. AIMS Geosciences, 3(4), 538-551.

Choi H.S. and Shin M. (1999), Hydrodynamics Study of Two Different Inverse Fluidized Reactors for the Application of Wastewater Treatment. Korean Journal of Chemical Engineering, 16(5), 670-676.
Dincer A.R., Karakaya N., Gunes E. and Gunes Y. (2008), Removal of COD from oil recovery industry wastewater by the Advanced Oxidation Processes (AOP) based on $\mathrm{H} 2 \mathrm{O} 2$, Global NEST Journal, 10, 31-38.

Ekins P., Vanner R. and Firebrace J. (2007), Zero emissions of oil in water from offshore oil and gas installations: economic and environmental implications, Journal of Cleaner Production, 15, 1302-1315.

Fakhrul-Razi A., Pendashteh A. and Abdullah L.C. (2009), Review of technologies for oil and gas produced water treatment. Journal of Hazardous Materials, 170, 30-51.

Fakharian H., Ganji H. and Naderifar A. (2017), Saline Produced Water Treatment Using Gas Hydrates. Journal of Environmental Chemical, 5(2), 4269-4273.

Fathy M., El-Sayed M., Ramzi M. and Abdelraheem O.H. (2017), Adsorption separation of condensate oil from produced water using ACTF prepared of oil palm leaves by batch and fixed bed techniques. Egyptian Journal of Petroleum, in press.

Hasan D.U.B., Abdul Aziz A.R. and Daud W.M.A.W. (2012), Oxidative mineralisation of petroleum refinery effluent using Fenton-like process. Chemical Engineering Research and Design, 90(2), 298-307.

Huang J. and Yan Z. (2018), Adsorption mechanism of oil by resilient graphene aerogels from oil-water emulsion. Langmuir, 1, 1-16.

Huang J. and Zhu J. (2017), Hydrodynamics in the Gas-Driven Inverse Liquid-Solid Fluidized Bed Electronic Thesis and Dissertation Repository, 4755.

Gasim H.A., Kutty S.R.M., Hasnain-Isa M. and Alemu L.T. (2013), Optimization of anaerobic treatment of petroleum refinery wastewater using artificial neural networks, Research Journal of Applied Sciences, Engineering and Technology, 6, 20772082.

Jian W., Kitanaka A., Nishijima W., Baes A.U. and Okada M. (1996), Removal of oil pollutants in seawater as pretreatment of reverse osmosis desalination process. Water Research, 33, 1857-1863.

Jiménez S., Micó M.M., Arnaldos M., Medina F. and Contreras S. (2017), State of the Art of Produced Water Treatment, Chemosphere, doi: 10.1016/j.chemosphere.2017.10.139.

Kavitha V. and Palanivelu K. (2004), The role of ferrous ion in Fenton and photo-Fenton processes for the degradation of phenol. Chemosphere, 55, 1235-1243.

Lathasree S., Rao N., Sivashankar B., Sadasivam V. and Rengaraj K. (2004), Heterogeneous photo catalytic mineralization of phenols in aqueous solutions, Journal of Molecular Catalysis A: Chemical, 223, 101-105.

Lee J.C. and Buckley P.S. (1981), Fluid mechanics and aeration characteristics of fluidised beds, in: Cooper P.F. and Atkinson B. (Eds.), Biological Fluidised Bed Treatment of Water and Wastewater, Ellis Horwood, Chichester, UK, 1981, pp. 62-74.

Luo Y., Jiang S., Xiao Q., Chen C. and Li B. (2017), Highly reusable and super hydrophobic spongy graphene aerogels for efficient oil/water separation. Scientific Reports, in press.

Mahani A.A., Motahari S. and Moheb A. (2017), Sol-gel derived flexible silica aerogel as selective adsorbent for water decontamination from crude oil. Marine Pollution Bulletin, in press.

Mohammed T.J. and Shakir E. (2017) Effect of settling time, velocity gradient, and camp number on turbidity removal for 
oilfield produced water. Egyptian Journal of Petroleum, in press.

Moulai-Mostefa N., Brou A., Ding L. and Joffrin M.Y. (2005), Ultrafiltration of oil in-water emulsions and cyclohexane micro-emulsions using a rotating disk system. Mecanique \& Industries, 6, 203-210.

Mukherjee A.K., Mishra B.K. and Ran V.K. (2009), Application of liquid/solid fluidization technique in beneficiation of fines. International Journal of Mineral Processing, 1-2, 67-73.

Mysore D., Viraraghavan T. and Jin Y. (2005), Treatment of oily waters using vermiculite. Water Research, 39, 2643-2653.

Okiel K., El-Sayed M. and El-Kady M.Y. (2011), Treatment of oilwater emulsions by adsorption onto activated carbon, bentonite and deposited carbon. Egyptian Journal of Petroleum, 20, 9-15.

Pardeshi S.K. and Patil A.B. (2008), A simple route for photocatalytic degradation of phenol in aqueous zinc oxide suspension using solar energy, Solar Energy, 82, 700-705.

Pasila A. (2004), A biological oil adsorption filter. Marine Pollution Bulletin, 49, 1006-1012.

Rajasimman M. and Karthikeyan C. (2009), Optimization studies in an Inverse Fluidized Bed Bioreactor for Starch Wastewater Treatment. International Journal of Environmental Research, 3(4), 569-574.

Ribeiro T.H., Rubio J. and Smith R.W. (2003), A dried hydrophobic aquaphyte as an oil filter for oil/water emulsions. Spill Science \& Technology Bulletin, 8, 483-489.

Saber A., Hasheminejad H., Taebi A. and Ghaffari G. (2014), Optimization of Fenton-based treatment of petroleum refinery wastewater with scrap iron using response surface methodology, Applied Water Science, 4, 283-290.

Slavko N., Vladimir M., Zvonimir B. and Adnan H. (2016), A new model for produced water treatment in elemir oil field. Archives for Technical Sciences, 15(1), 27-33.

Sokoła W., Ambaw A. and Woldeyes B. (2009), Biological wastewater treatment in the inverse fluidized bed reactor. Chemical Engineering Journal, 150, 63-68.

Tisa F., Abdul Raman A.A. and Daud W.M.A.W. (2014), Basic Design of a Fluidized Bed Reactor for Wastewater Treatment Using Fenton Oxidation. International Journal of Innovation, Management and Technology, 5(2), 93-98.

Tony M.A., Patrick J. and Purcell Yaqian Z. (2012), Oil refinery wastewater treatment using physicochemical, Fenton and Photo-Fenton oxidation processes, Journal of Environmental Science and Health, Part A, 47, 435-440.

Tony M.A., Zhao Y.Q., Purcell P.J. and El-Sherbiny M.F. (2009), Evaluating the photo-catalytic application of Fenton's reagent augmented with $\mathrm{TiO} 2$ and $\mathrm{ZnO}$ for the mineralization of an oil-water emulsion, J. Environ. Sci. Health A, 44(5), 488493.

Veil J., Puder M.G., Elcock D. and Redweik R.J.J. (2004), A white paper describing produced water from production of crude oil, natural gas and coal bed methane. Lemont, IL: Argonne National Laboratory. Available at http://www.netl.doe.gov/ publications/oil pubs/prodwaterpaper.pdf.

Viraraghavam T. and Moazed H. (2003), Removal of oil from water by bentonite. Fresenius Environmental Bulletin, 12, 1092-1097.

Upender H. and Kishore A.K. (2017), Minimum Fluidization Velocity studies by using Pressure Drop in Inverse Fluidization. 5th International Conference on Advancement in Engineering, Applied Science and Management (ICAEASM2017).

Wang S., Wang X., Wang X., Shao B., Ma Y., Sun Q. and Zhao J. (2018), Numerical simulation of flow behavior of particles in an inverse liquid-solid fluidized bed with a jet using CFDDEM. Journal of the Taiwan Institute of Chemical Engineers, 82, 214-225.

Wang B., Yi W., Yingxin G., Guomao Z., Min Y., Song W. and Jianying H. (2015), Occurrences and behaviors of Naphthenic Acids in a petroleum refinery wastewater treatment plant, Environmental Science \& Technology, 49, 5796-5804.

Wang D., Silbaugh T., Pfeffer R. and Lin Y.S. (2010), Removal of emulsified oil from water by inverse fluidization of hydrophobic aerogels. Powder Technology, 203, 298-309.

Yang X. (2008), Sol-gel synthesized nanomaterials for environmental applications. PhD Thesis, Kansas State University.

Yu L., Han M. and He F. (2017), A review of treating oily wastewater. Arabian Journal of Chemistry, 10, S1913-S1922.

Zhao X., Wang Y., Ye Z., Borthwick A.G.L. and Ni J. (2006), Oil field wastewater treatment in Biological Aerated Filter by immobilized microorganisms, Process Biochemistry, 41, 1475-1483. 